\title{
SCREENING OF MAIZE GENOTYPES AGAINST SOUTHERN LEAF BLIGHT (ipolaris maydis) DURING SUMMER IN RAMPUR, CHITWAN, NEPAL
}

\author{
P. B. Magar ${ }^{1}$, G. B. Khatri-Chhetri ${ }^{1}$, S. M. Shrestha ${ }^{1}$ and T. R. Rijal ${ }^{2}$ \\ ${ }^{1}$ Institute of Agriculture and Animal Sciences, Tribhuvan University, Nepal \\ ${ }^{2}$ Nepal Agriculture Research Council, Kathmandu, Nepal
}

\begin{abstract}
A study was conducted during June to September, 2012, in the field at National Maize Research Program, Rampur, Chitwan, Nepal with the objective of screening 20 maize genotypes against southern leaf blight caused by Bipolaris maydis. Experiment was laid out in a randomized complete block design with three replications. Disease scoring was done as percentage of leaf area infected on individual plant at 7 days intervals starting from 50 days after sowing, for 6 times, and disease severity and mean AUDPC were calculated and yield recorded. Among the tested genotypes, there was variation in disease severity and mean AUDPC values. Disease severity was maximum on Yellow Popcorn (51.67\%) and least on RML-32/RML-17 (7.27\%). Based on mean AUDPC values, RML-32/RML-17 (20.53) appeared most resistant, followed by RML-4/NML-2 (23.66) and RML-4/RML-17 (25.90), while Yellow Popcorn (136.9) was found the most susceptible. Highest grain yield (4.90 t/ha) was also recorded on RML-32/RML-17 and least (2.49 t/ha) on Yellow Popcorn. Therefore the genotypes RML-32/RML-17, RML-4/NML-2 and RML-4/RML-17 could be used as the resistant varieties and source of resistance to southern leaf blight for varietal development of maize.
\end{abstract}

Key words: AUDPC; Bipolaris $\underline{\text { maydis; }}$; disease scoring; genotypes; resistant

\section{INTRODUCTION}

Southern leaf blight (SLB) of maize, caused by Bipolaris maydis syn. Helminthosporium maydis (Teliomorph: Cochliobolus hetrostrophus) is considered as the important one creating a threat to successful maize cultivation in low lands of Nepal during summer. The disease has been occurring in terai, inner-terai and mid-hills (lower elevation) since many years in summer and winter maize in Nepal (Paudel and Koirala, 1995). Severity is increasing in terai. Disease data from the experimental trail and disease situation observed in farmer's field indicate the need for screening the genotypes against SLB (Paudel and Basnet, 2003). Bipolaris maydis "race O" resistance has been described as quantitative, with a predominance of additive gene action as well as significant dominance effects present in some population (Lim, 1975; Lim and Hooker, 1976; Thompson and Bergquist, 1984 and Burnette and White, 1985) while Smith and Hooker (1973) suggested as qualitative resistance inherited as a single recessive gene, designated as rhm 1. Since for controlling the disease by the use of fungicides is costly and environment unfriendly while the use of resistant varieties is simple, effective, safe and economical therefore, identification of resistant genotypes/varieties would be good alternatives to manage SLB. The objective of this study was to assess the level of resistance on different maize genotypes against SLB during summer in the field conditions of Rampur, Chitwan, Nepal. 


\section{MATERIALS AND METHODS}

\section{Experimental setup and sowing}

Field experiment was conducted at National Maize Research Program (NMRP), Rampur, Chitwan, Nepal during summer season (June to September, 2012) under rainfed condition The site lies in the sub-tropical zone with an altitude of 228 masl, between $27^{\circ} 39^{\prime} 38^{\prime \prime} \mathrm{N}$ latitude and $84^{\circ} 21^{\prime}$ ' $14^{\prime}$ ' E longitude. The experiment was designed in a randomized complete block with 3 replications. Individual plot size was $7.5 \mathrm{~m}^{2}(5 \mathrm{~m} \times 1.5 \mathrm{~m})$ and total area of the research field was $705 \mathrm{~m}^{2}$. There were 2 rows of $5 \mathrm{~m}$ length/plot and row to row spacing was $75 \mathrm{~cm}$. Plant to plant spacing was $25 \mathrm{~cm}$. The susceptible check variety, "Yellow Popcorn" was sown in 2 rows around the entire field, with one row between each replication block and one row after each 5 plots within the block, to provide a uniform source of inoculum.

Seeds of twenty maize genotypes originating from diverse sources were obtained from NMRP, Rampur, Chitwan and were sown on June 1, 2012 @ 2 seeds/hill with a Zab planter. The chemical fertilizer was applied at the rate of 120:60:40 kg NPK/ha through urea $(46 \% \mathrm{~N})$, DAP $(18 \% \mathrm{~N}$ and $\left.46 \% \mathrm{P}_{2} \mathrm{O}_{5}\right)$ and MOP $\left(60 \% \mathrm{~K}_{2} \mathrm{O}\right)$ along with FYM @ 10 t/ha. Half dose of $\mathrm{N}$ and full dose of P and $\mathrm{K}$ were applied as a basal dose during final land preparation and remaining half dose of $\mathrm{N}$ was top dressed 45 days after sowing (DAS). Thinning was done 30 DAS in all plots to maintain desired plant population. To control borer, 3 to 4 furadane granules were applied once to the whorl of each plant manually at 45 DAS. Two manual weedings and hoeings were done at knee high stage and before tasseling to control weeds.

\section{Disease assessment}

Randomly selected 10 plants (5 plants from each row) were tagged from each plot for disease scoring. Disease incidence was recorded immediately after appearance of disease, and disease scoring was started 14 days after disease appearance. Severity of southern leaf blight was measured as percentage of leaf area infected on individual plant visually at 7 days intervals. A total of 6 scorings were done from July to August, 2012, i.e. July 21, July 28, August 11, August 18 and August 25. Disease scoring was done on using $1-5$ scale as given below.

$1=$ Plants with one or two to few scattered lesions on lower leaves (Resistant)

$2=$ Moderate number of lesions on leaves, affecting $<25 \%$ of the leaf area (Moderately Resistant)

$3=$ Abundant lesions on lower leaves, few on other leaves affecting 26-50\% leaf area (Moderately Susceptible)

4 = Lesions abundant on lower and mid leaves, extending to upper leaves affecting $51-75 \%$ leaf area (Susceptible)

$5=$ Lesions abundant on almost all leaves, plants prematurely dried or killed with $76-100 \%$ of the leaf area affected (Highly Susceptible)

Percent disease intensity was calculated using the following formula:

Disease intensity $(\%)=\frac{\text { Sum of all numerical ratings } \times 100}{\text { Total no. of plants observed } \times \text { maximum rating }}$

Disease intensity per plant was calculated and mean intensity was computed for each plot.

Reynolds and Neher (1997) states that area under disease progress curve (AUDPC) provides a quantitative measure of disease development and intensity of disease, and the variety having the 
lowest AUDPC value was categorized as the most resistant, while susceptible one has higher values. AUDPC value was calculated by using the following formula as given by Das et al. (1992).

n-1

$$
\begin{aligned}
& \mathrm{AUDPC} \\
& \mathrm{i}=1
\end{aligned}
$$

where, $\mathrm{Y}_{\mathrm{i}}=$ disease severity on the $\mathrm{i}^{\text {th }}$ date,

$\mathrm{t}_{\mathrm{i}}=$ time on which $\mathrm{Y}_{\mathrm{i}}$ was recorded and

$\mathrm{n}=$ number of times observations were taken.

Based on the mean AUDPC values, the genotypes were categorized into 4 groups of resistance level as below:

$$
\begin{aligned}
& \text { Mean AUDPC value } \\
& 1-30 \\
& 31-60 \\
& 61-90 \\
& >90
\end{aligned}
$$

\author{
Resistance category \\ Resistant \\ Moderately resistant \\ Susceptible \\ Highly susceptible
}

\section{Code \\ $\mathrm{R}$ \\ MR \\ $\mathrm{S}$ \\ HS}

\section{Agronomic traits}

Crop was harvested at maturity on September 12, 2012 from whole plot area and grain yield (t/ha) was adjusted to $15 \%$ moisture level using the following formula.

Grain yield $(\mathrm{t} / \mathrm{ha})$ at $15 \%$ moisture $=\frac{\mathrm{FW}(\mathrm{kg}) \times(100-\mathrm{MC} \%) \times 0.8 \times 10}{\text { Net harvested area }\left(\mathrm{m}^{2}\right) \times 85}$

Where, $\mathrm{FW}=$ Fresh Weight and $\mathrm{MC}=$ Moisture Content

\section{Statistical analysis}

The data were processed to fit into MSTAT-C (Freed and Scott, 1986) software for analysis. MS-excel (2007) program was used for data tabulation, and duncan's multiple range test (DMRT) was done at $5 \%$ level of significance for mean comparison from the reference of Gomez and Gomez (1984). Analysis of variance (ANOVA) was used to test differences among the genotypes and DMRT was applied to identify the most resistant varieties.

\section{Disease incidence and severity}

\section{RESULTS AND DISCUSSION}

Symptoms of southern leaf blight appeared in all maize genotypes 36 to 48 days after sowing (DAS), i.e. on $7^{\text {th }}$ and $19^{\text {th }}$ July, 2012, respectively and differed significantly from each other at $5 \%$ level. Symptoms were observed at first on Yellow popcorn i.e. 36 DAS on $7^{\text {th }}$ July, 2012, whereas on RML-32/RML-17 disease appeared on 48 DAS.

The twenty maize genotypes also varied considerably in SLB severity at 86 DAS, and it ranged from $7.27 \%$ to $51.67 \%$ (Table 1). Highest severity was found on Yellow Popcorn $(51.67 \%$ ), while RML-32/RML-17 (7.27\%), RML-4/NML-2 (8.10\%) and RML-4/RML-17 (8.27\%) had significantly lower severity. Yellow popcorn had earliest symptoms and maximum disease severity in comparison to other genotypes. This might be due to rapid disease development and higher susceptibility of the host to the pathogen. Similarly, late most appearance of the disease with lower disease severity on RML-32/RML-17 might be due to slower disease development and resistance of host to the pathogen. 
Table 1. Number of days for disease appearance after sowing and SLB severity percent on 20 maize genotypes at Rampur, Chitwan, Nepal, 2012

\begin{tabular}{|c|c|c|}
\hline Treatments & $\begin{array}{l}\text { Appearance of symptoms } \\
\text { (DAS) }\end{array}$ & $\begin{array}{l}\text { Severity of SLB }(\%) \\
(86 \mathrm{DAS})\end{array}$ \\
\hline 1. RML-32/RML-17 & $48.00^{\mathrm{a}}$ & $7.267^{\mathrm{h}}$ \\
\hline 2. RML-4/NML-2 & $46.67^{b}$ & $8.100^{\mathrm{h}}$ \\
\hline 3. RML-4/RML-17 & $43.00^{\mathrm{gh}}$ & $8.267^{\mathrm{gh}}$ \\
\hline 4. RML-8/R.C. & $46.33^{\mathrm{bc}}$ & $10.83^{\text {fgh }}$ \\
\hline 5. BLSBS07F10 & $44.33^{\mathrm{def}}$ & $11.60^{\mathrm{efgh}}$ \\
\hline 6. Celaya00HGYA/00HGYB & $44.67^{\mathrm{de}}$ & $11.63^{\text {efgh }}$ \\
\hline 7. $\mathrm{HG}-\mathrm{A}$ & $42.33^{\mathrm{hij}}$ & $11.90^{\text {defgh }}$ \\
\hline 8. TLBRS07F16 & $43.33^{\text {fgh }}$ & $13.73^{\text {cdefg }}$ \\
\hline 9. Rampur S10F20 & $43.00^{\mathrm{gh}}$ & $14.10^{\text {cdef }}$ \\
\hline 10. BLSBS07F12 & $42.33^{\text {hij }}$ & $14.27^{\text {cdef }}$ \\
\hline 11. TPY & $39.33^{\mathrm{k}}$ & $14.47^{\text {cdef }}$ \\
\hline 12. R-POP-3 & $45.33^{\mathrm{cd}}$ & $16.17^{\text {cdef }}$ \\
\hline 13. Rampur S10F18 & $44.33^{\text {def }}$ & $16.73^{\text {cde }}$ \\
\hline 14. $\mathrm{HG}-\mathrm{B}$ & $43.67^{\mathrm{efg}}$ & $17.27^{\mathrm{cd}}$ \\
\hline 15. TLBRS07F14 & $42.67^{\text {ghi }}$ & $17.73^{\mathrm{c}}$ \\
\hline 16. $\mathrm{HG}-\mathrm{A} / \mathrm{HG}-\mathrm{AB}$ & $41.67^{\mathrm{ij}}$ & $17.80^{\mathrm{c}}$ \\
\hline 17. Across $9331 \mathrm{RE}$ & $41.33^{\mathrm{j}}$ & $17.90^{\mathrm{c}}$ \\
\hline 18. $\mathrm{HG}-\mathrm{AB}$ & $38.67^{\mathrm{k}}$ & $23.90^{\mathrm{b}}$ \\
\hline 19. Rampur S03F06 & $38.33^{\mathrm{k}}$ & $26.47^{\mathrm{b}}$ \\
\hline 20. Yellow popcorn & $36.33^{1}$ & $51.67^{\mathrm{a}}$ \\
\hline S.Em $( \pm)$ & 0.3894 & 1.477 \\
\hline $\operatorname{LSD}(0.05)$ & 1.115 & 5.370 \\
\hline CV (\%) & 1.58 & 15.42 \\
\hline Probability & $0.0000 * *$ & $0.0000 * *$ \\
\hline
\end{tabular}

DAS: Days after sowing, SLB: Southern leaf blight, CV: Coefficient of variation, LSD: Least significant difference, Means followed by the same letter in a column are not significantly different by DMRT at $5 \%$ level of significance, SEm $( \pm)$ indicates standard error of mean

\section{Area under disease progress curve}

The genotypes varied significantly in area under disease progress curve (AUDPC) values in all 5 observation dates. AUDPC values increased with time of observation in all the genotypes (Table 2). The genotype RML-32/RML-17 had the lowest and Yellow Popcorn had the highest AUDPC values in all observation dates, with a mean value of 20.53 and 136.90, respectively (Table 2 and 3 ). The genotypes RML-4/NML-2 (23.66) and RML-4/RML-17 (25.90) also did not differ significantly from RML-32/RML-17 (20.53). The variation in disease increment might be due to variation in susceptibility of genotypes to the pathogen. Yellow popcorn (136.90) showed drastically highest mean AUDPC value as compared to the genotype Rampur S03F06 (79.05), with the $2^{\text {nd }}$ highest mean AUDPC value (Table 3). This result was also supported by Paudel et al. (2007) and Paudel and Rijal (2009) that Yellow Popcorn was the most susceptible genotype to SLB in terai and inner terai of Nepal. 
Based on the mean AUDPC values, the twenty maize genotypes could be categorized into four resistance levels, i.e. resistant, moderately resistant, susceptible and highly susceptible. Among them, only three genotypes, RML-32/RML-17 (AUDPC value 20.53), RML-4/NML-2 (23.66) and RML-4/RML-17 (25.90) were found resistant, while only the genotype Yellow Popcorn (136.9) was found highly susceptible (Table 3). Twelve genotypes were found moderately resistant and four were susceptible.

Table 2. AUDPC values of Southern leaf blight in different dates at Rampur, Chitwan, Nepal

\begin{tabular}{|c|c|c|c|c|c|c|}
\hline \multicolumn{2}{|c|}{ Treatments } & $\begin{array}{l}\text { July } 28 \\
\text { (58 DAS) }\end{array}$ & $\begin{array}{l}\text { August } 4 \\
\text { (65 DAS) }\end{array}$ & $\begin{array}{l}\text { August } 11 \\
\text { (72 DAS) }\end{array}$ & $\begin{array}{l}\text { August } 18 \\
\text { (79 DAS) }\end{array}$ & $\begin{array}{l}\text { August } 25 \\
\text { (86 DAS) }\end{array}$ \\
\hline \multicolumn{2}{|c|}{ 1. RML-32/RML-17 } & $7.00^{\mathrm{k}}$ & $8.633^{\mathrm{j}}$ & $17.38^{\mathrm{i}}$ & $28.23^{\mathrm{i}}$ & $41.42^{\mathrm{i}}$ \\
\hline \multicolumn{2}{|c|}{ 2. RML-4/NML-2 } & $10.50^{\text {ghijk }}$ & $12.13^{\mathrm{ij}}$ & $21.00^{\mathrm{i}}$ & $30.33^{\mathrm{i}}$ & $44.33^{\mathrm{i}}$ \\
\hline \multicolumn{2}{|c|}{ 3. RML-4/RML-17 } & $9.04^{\mathrm{ijk}}$ & $11.84^{\mathrm{ij}}$ & $21.93^{\mathrm{i}}$ & $36.40^{\text {hi }}$ & $50.28^{\mathrm{hi}}$ \\
\hline \multicolumn{2}{|c|}{ 4. RML-8/R.C. } & $10.62^{\text {fghijk }}$ & $13.30^{\mathrm{hij}}$ & $26.83^{\mathrm{hi}}$ & $45.15^{\text {ghi }}$ & $63.82^{\text {ghi }}$ \\
\hline \multicolumn{2}{|c|}{ 5. BLSBS07F12 } & $11.90^{\text {fghij }}$ & $14.23^{\text {ghij }}$ & $27.77^{\mathrm{hi}}$ & $44.22^{\text {ghi }}$ & $74.20^{\mathrm{fgh}}$ \\
\hline \multicolumn{2}{|c|}{ 6. R-POP-3 } & $8.63^{\mathrm{jks}}$ & $12.60^{\mathrm{hij}}$ & $25.90^{\mathrm{hi}}$ & $43.52^{\text {ghi }}$ & $81.90^{\text {efg }}$ \\
\hline \multicolumn{2}{|c|}{ 7. Celaya00HGYA/00HGYB } & $10.03^{\text {hijk }}$ & $14.82^{\text {ghij }}$ & $33.95^{\text {fghi }}$ & $53.32^{\text {fghi }}$ & $69.53^{\text {ghi }}$ \\
\hline \multicolumn{2}{|c|}{ 8. TPY } & $14.58^{\text {cdefg }}$ & $18.32^{\text {efghi }}$ & $31.50^{\text {ghi }}$ & $49.12^{\text {fghi }}$ & $77.82^{\text {fgh }}$ \\
\hline \multicolumn{2}{|c|}{ 9. BLSBS07F10 } & $12.25^{\text {efghij }}$ & $14.58^{\text {ghij }}$ & $34.77^{\text {fghi }}$ & $60.43^{\text {efgh }}$ & $74.43^{\text {fgh }}$ \\
\hline 10. & TLBRS07F16 & $14.00^{\text {defgh }}$ & $16.10^{\text {fghi }}$ & $33.95^{\text {fghi }}$ & $57.17^{\text {efghi }}$ & $79.92^{\mathrm{fg}}$ \\
\hline 11. & $\mathrm{HG}-\mathrm{A}$ & $16.57^{\text {cde }}$ & $19.60^{\text {cdefgh }}$ & $36.98^{\text {fghi }}$ & $64.87^{\mathrm{efgh}}$ & $80.15^{\mathrm{fg}}$ \\
\hline 12. & Rampur S10F20 & $16.80^{\mathrm{cd}}$ & $20.77^{\text {cdefg }}$ & $43.05^{\text {efgh }}$ & $71.05^{\mathrm{defg}}$ & $88.90^{\mathrm{defg}}$ \\
\hline 13. & Rampur S10F18 & $13.53^{\text {defgh }}$ & $19.02^{\text {defghi }}$ & $43.63^{\text {defgh }}$ & $75.60^{\text {cdef }}$ & $102.20^{\text {def }}$ \\
\hline 14. & Across $9331 \mathrm{RE}$ & $16.57^{\text {cde }}$ & $23.92^{\text {cde }}$ & $48.88^{\text {cdefg }}$ & $84.12^{\text {cde }}$ & $112.50^{\mathrm{d}}$ \\
\hline 15. & $\mathrm{HG}-\mathrm{B}$ & $18.90^{\mathrm{c}}$ & $26.95^{\mathrm{c}}$ & $53.43^{\text {cdef }}$ & $85.87^{\text {cde }}$ & $109.70^{\mathrm{de}}$ \\
\hline 16. & TLBRS07F14 & $13.42^{\text {defgh }}$ & $19.83^{\text {cdefgh }}$ & $57.98^{\text {bcde }}$ & $100.40^{\mathrm{bc}}$ & $116.20^{\mathrm{cd}}$ \\
\hline 17. & $\mathrm{HG}-\mathrm{AB}$ & $13.30^{\text {defghi }}$ & $26.02^{\mathrm{cd}}$ & $63.82^{\mathrm{bcd}}$ & $104.80^{\mathrm{bc}}$ & $143.10^{\mathrm{bc}}$ \\
\hline 18. & $\mathrm{HG}-\mathrm{A} / \mathrm{HG}-\mathrm{AB}$ & $33.60^{\mathrm{b}}$ & $53.90^{\mathrm{b}}$ & $77.23^{b}$ & $97.30^{\mathrm{bcd}}$ & $110.80^{\mathrm{d}}$ \\
\hline 19. & Rampur S03F06 & $14.93^{\text {cdef }}$ & $22.28^{\text {cdef }}$ & $64.28^{\mathrm{bc}}$ & $125.70^{\mathrm{b}}$ & $168.10^{\mathrm{b}}$ \\
\hline 20. & Yellow popcorn & $52.03^{\mathrm{a}}$ & $72.45^{\mathrm{a}}$ & $115.30^{\mathrm{a}}$ & $170.00^{\mathrm{a}}$ & $275.00^{\mathrm{a}}$ \\
\hline SEn & & 1.145 & 1.931 & 5.301 & 7.689 & 7.446 \\
\hline LSL & $.05)$ & 4.162 & 7.021 & 19.27 & 27.95 & 27.07 \\
\hline $\mathrm{CV}$ & & 12.46 & 15.16 & 20.88 & 18.66 & 13.13 \\
\hline Prol & ility & $0.0000 * *$ & $0.0000 * *$ & $0.0000 * *$ & $0.0000 * *$ & $0.0000 * *$ \\
\hline
\end{tabular}

DAS: Days after sowing, CV: Coefficient of variation; LSD: Least significant difference: Means followed by the same letter in a column are not significantly different by DMRT at $5 \%$ level of significance, SEm $( \pm)$ indicates standard error of mean 
Table 3. Resistance category of 20 maize genotypes on the basis of mean AUDPC values in field during June to September, 2012, at Rampur, Chitwan, Nepal

\begin{tabular}{|c|c|c|c|c|}
\hline \multicolumn{2}{|c|}{ Genotypes } & \multirow{2}{*}{$\begin{array}{l}\text { Mean AUDPC } \\
\text { value } \\
20.53^{\mathrm{k}}\end{array}$} & \multirow[t]{2}{*}{$\begin{array}{l}\text { No. of } \\
\text { Genotypes }\end{array}$} & \multirow[t]{2}{*}{$\begin{array}{l}\text { Resistance } \\
\text { category }\end{array}$} \\
\hline 1. & RML-32/RML-17 & & & \\
\hline 2. & RML-4/ NML-2 & $23.66^{\mathrm{jk}}$ & \multirow[t]{2}{*}{3} & \multirow[t]{2}{*}{$\mathrm{R}$} \\
\hline 3. & RML-4/RML-17 & $25.90^{\mathrm{ijk}}$ & & \\
\hline 4. & RML-8/ R.C. & $31.94^{\text {hijk }}$ & \multirow{12}{*}{12} & \multirow{12}{*}{ MR } \\
\hline 5. & BLSBS07F12 & $34.46^{\mathrm{hij}}$ & & \\
\hline 6. & R-POP-3 & $34.51^{\text {hij }}$ & & \\
\hline 7. & Celaya 00HGYA/00HGYB & $36.33^{\text {ghij }}$ & & \\
\hline 8. & TPY & $38.27^{\text {fghi }}$ & & \\
\hline 9. & BLSBS07F10 & $39.29^{\text {fgh }}$ & & \\
\hline 10. & TLBRS07F16 & $40.23^{\mathrm{fgh}}$ & & \\
\hline 11. & $\mathrm{HG}-\mathrm{A}$ & $43.63^{\mathrm{fgh}}$ & & \\
\hline 12. & Rampur S10F20 & $48.11^{\mathrm{efg}}$ & & \\
\hline 13. & Rampur S10F18 & $50.80^{\text {def }}$ & & \\
\hline 14. & Across $9331 \mathrm{RE}$ & $57.19^{\text {de }}$ & & \\
\hline & HG-B & $58.96^{\text {cde }}$ & & \\
\hline & TLBRS07F14 & $61.58^{\mathrm{cd}}$ & \multirow{4}{*}{4} & \multirow{4}{*}{$\mathrm{S}$} \\
\hline 17. & $\mathrm{HG}-\mathrm{AB}$ & $70.21^{\mathrm{bc}}$ & & \\
\hline & $\mathrm{HG}-\mathrm{A} / \mathrm{HG}-\mathrm{AB}$ & $74.57^{\mathrm{b}}$ & & \\
\hline 19. & Rampur S03F06 & $79.05^{\mathrm{b}}$ & & \\
\hline \multicolumn{2}{|c|}{ 20. Yellow popcorn } & $136.90^{\mathrm{a}}$ & 1 & $\mathrm{HS}$ \\
\hline \multicolumn{2}{|c|}{$\operatorname{SEm}( \pm)$} & 4.067 & & \\
\hline \multicolumn{2}{|c|}{$\operatorname{LSD}(0.05)$} & 11.64 & & \\
\hline \multicolumn{2}{|c|}{ CV $(\%)$} & 14.00 & & \\
\hline \multicolumn{2}{|c|}{ Probability } & $0.0000 * *$ & & \\
\hline
\end{tabular}

R: Resistant, MR: Moderately resistant, S: Susceptible, HS: Highly susceptible, CV: Coefficient of variation; LSD: Least significant difference: Means followed by the same letter in a column are not significantly different by DMRT at 5\% level of significance, SEm $( \pm)$ indicates standard error of mean

\section{Yield and thousand kernel weight}

Grain yield and 1000 kernel weight varied significantly among the genotypes. Maximum grain yield (4.90 t/ha) was recorded in RML-32/RML-17, while minimum (2.49 t/ha) in yellow popcorn (Table 4). However, grain yield of RML-32/RML-17 did not differ significantly with the yield of RML-4/RML-17 (4.43 t/ha), RML-8/R.C. (4.36 t/ha) and RML-4/NML-2 (4.270 t/ha).

Similarly, thousand kernel weight (TKW) differed significantly among the 20 maize genotypes (Table 4). The TKW ranged from $160.00 \mathrm{~g}$ to $425.30 \mathrm{~g}$. Highest TKW (425.30 g) was found in RML-4/RML-17 and lowest in Yellow popcorn (160.00 g) (Table 4). Statistically the TKWs were highly significant among the genotypes.

From the result, it was found that the genotype, Yellow Popcorn, showing the maximum disease severity (51.67\%), also showed the highest mean AUDPC value (136.9) and least yield (2.49 $\mathrm{t} / \mathrm{ha}$ ) among the tested genotypes. So, this genotype appeared as the most susceptible genotype to southern leaf blight among all the tested genotypes in field under epiphytotic condition. Similarly, the 
genotype RML-32/RML-17 showed the highest maximum yield (4.90 t/ha) with the lowest disease severity (7.27\%) and the least mean AUDPC value (20.53). But with TKW, highest TKW (425.30 g) was found in RML-4/RML-17 and it might be due to small grain size and higher number of grains per cob in RML-32/RML-17.

Table 4. Yield and thousand kernel weight of 20 maize genotypes at Rampur, Chitwan, Nepal, 2012

\begin{tabular}{|c|c|c|}
\hline Treatments & Yield (t/ha) & Thousand kernel weight $(\mathrm{g})$ \\
\hline 1. RML-32/RML-17 & $4.90^{\mathrm{a}}$ & $368.00^{\mathrm{ab}}$ \\
\hline 2. RML-4/RML-17 & $4.43^{\mathrm{ab}}$ & $425.30^{\mathrm{a}}$ \\
\hline 3. RML-4/NML-2 & $4.27^{\mathrm{abc}}$ & $346.70^{\mathrm{abc}}$ \\
\hline 4. RML-8/R.C. & $4.36^{\mathrm{ab}}$ & $360.00^{\mathrm{ab}}$ \\
\hline 5. TLBRS07F16 & $4.09^{\mathrm{bcd}}$ & $365.30^{\mathrm{ab}}$ \\
\hline 6. BLSBS07F10 & $3.76^{\text {bcde }}$ & $356.00^{\mathrm{abc}}$ \\
\hline 7. Rampur S10F20 & $3.72^{\text {bcde }}$ & $337.30^{\mathrm{abc}}$ \\
\hline 8. TPY & $3.62^{\text {cde }}$ & $302.70^{\mathrm{bc}}$ \\
\hline 9. BLSBS07F12 & $3.45^{\text {def }}$ & $366.70^{\mathrm{ab}}$ \\
\hline 10. R-POP-3 & $3.24^{\mathrm{ef}}$ & $372.00^{\mathrm{ab}}$ \\
\hline 11. Celaya 00HGYA/00HGYB & $3.20^{\mathrm{efg}}$ & $320.00^{\mathrm{bc}}$ \\
\hline 12. HG-A & $3.19^{\text {efg }}$ & $336.00^{\mathrm{abc}}$ \\
\hline 13. HG-B & $3.02^{\mathrm{efg}}$ & $285.30^{\mathrm{bc}}$ \\
\hline 14. Across $9331 \mathrm{RE}$ & $3.14^{\mathrm{efg}}$ & $305.30^{\mathrm{bc}}$ \\
\hline 15. Rampur S10F18 & $2.80^{\mathrm{fg}}$ & $329.30^{\mathrm{abc}}$ \\
\hline 16. HG-A/HG-AB & $3.73^{\text {bcde }}$ & $257.30^{\mathrm{cd}}$ \\
\hline 17. HG-AB & $3.55^{\text {cdef }}$ & $318.70^{\mathrm{bc}}$ \\
\hline 18. TLBRS07F14 & $3.49^{\mathrm{def}}$ & $326.70^{\mathrm{abc}}$ \\
\hline 19. Rampur S03F06 & $3.22^{\mathrm{ef}}$ & $356.00^{\mathrm{abc}}$ \\
\hline 20. Yellow popcorn & $2.49^{\mathrm{g}}$ & $160.00^{\mathrm{d}}$ \\
\hline $\operatorname{SEm}( \pm)$ & 0.2887 & 26.75 \\
\hline $\operatorname{LSD}(0.05)$ & 1.049 & 97.24 \\
\hline CV (\%) & 16.34 & 14.05 \\
\hline Probability & $0.0000 * *$ & $0.0000 * *$ \\
\hline
\end{tabular}

t/ha: Ton per hectare, g: Gram, R: Resistant, MR: Moderately resistant, S: Susceptible, HS: Highly susceptible, CV: Coefficient of variation, LSD: Least significant difference, Means followed by the same letter in a column are not significantly different by DMRT at 5\% level of significance, SEm $( \pm)$ indicates standard error of mean

\section{CONCLUSION AND RECOMMENDATION}

Since the maize genotypes varied highly in southern leaf blight severity, screening of genotypes seemed to be one of the important techniques for finding the sources of resistant. Among the 20 maize genotypes, RML-32/RML-17, RML-4/NML-2 and RML-4/RML-17 appeared resistant to southern leaf blight of maize. These genotypes could be used for farmers' adoption and also as sources of resistance in breeding program for varietal development. Because the experiment was conducted in only one year, to confirm the disease reaction of the tested genotypes, verification testing at least for one more year is required. 


\section{ACKNOWLEDGEMENTS}

The authors acknowledge to National Maize Research Program (NMRP), Rampur for providing the maize genotypes. National Agriculture Research and Development Fund (NARDF), Nepal was highly acknowledged for granting financial support. Suggestion and guidance from the members of the advisory committee is highly acknowledged.

\section{REFERENCES CITED}

Burnette, D.C. and D.G. White. 1985. Inheritance of resistance to Bipolaris maydis race O in crosses derived from nine resistance inbred lines of maize. Phytopathology. 75: 1195-1200.

Das, M.K., S. Rajaram, C.C. Mundt and W.E. Kronstad. 1992. Inheritance of slow rusting resistance to leaf rust in wheat. Crop Science. 32: 1452-1456.

Freed R.D. and D.E. Scott. 1986. MSTATC. Crop and soil. Michigan: Michigan State University, USA.

Gomez K.A. and A.A. Gomez. 1984. Statistical procedures for agricultural research $\left(2^{\text {nd }} e d\right)$. A Wiley Interscience Publication, New York, USA. 655p.

Leath, S., R.P. Thakur and K.J. Leonard. 1990. Variation on expression of monogenic resistance in corn to Exserohilum turcicum race 3 under different temperature and high regimes. Phytopathology. 80: 309-313.

Lim, S.M. 1975. Heterotic effects of resistance in maize to Helminthosporium maydis race O. Phytopathology. 65: 1117-1120.

Lim, S.M. and A.L. Hooker. 1976. Estimates of combining ability for resistance to Helminthosporium maydis race $\mathrm{O}$ in a maize population. Maydica. 21: 121-128.

Paudel D.C., T.R. Rijal and N. Tripathi. 2007. Tolerance and resistance of maize genotypes against southern leaf blight disease. pp, 256-262. In: Proceedings of the $25^{\text {th }}$ National Summer Crops Research Workshop. NMRP, Rampur, Chitwan.

Paudel, D.C. and T.R. Rijal. 2009. Screening of maize genotypes against southern leaf blight. pp, 10-13. In: Annual Report, 2010. NMRP, Rampur, Chitwan.

Paudel, D.C. and K.B. Koirala. 1995. Pathological report on breeding trial and nurseries (19921994). Paper presented at the eighteenth Summer Crops Workshop held at NMRP, Rampur. March 1-2, 1995. 15p.

Paudel, D.C. and R. Basnet. 2003. Screening of maize inbreds against southern leaf blight. pp, 235237. In: Proceedings of the $24^{\text {th }}$ National Summer Crops Research Workshop. NMRP, Rampur, Chitwan.

Reynolds, L. and D.A. Neher. 1997. Statistical comparison of epidemics, In: L.J. Francl and D.A. Neher (Eds.). Exercises in plant disease epidemiology, pp. 34-37, St. Paul, USA, APS Press.

Smith, D.R. andA.L.Hooker. 1973. Monogenic chlorotic-lesion resistance in corn to Helminthosporium maydis. Crop Science. 13: 330-331.

Thompson, D.L. and R.R. Bergquist. 1984. Inheritance of mature plant resistance to Helminthosporium maydis race $\mathrm{O}$ in maize. Crop Science. 24: 807-811. 